\title{
Tudo o que é sólido se desmancha no futuro: percepções imaginárias do corpo em filmes futuristas
}

\author{
Eduardo Duartel \\ https://orcid.org/0000-0002-7272-0088 \\ Gustavo Ramos' \\ https://orcid.org/0000-0002-5117-9093 \\ I - Universidade Federal de Pernambuco \\ Recife (PE). Brasil.
}

Resumo: O presente estudo investiga as projeções do imaginário social sobre o futuro do corpo humano na imagem cinematográfica da ficção científica. Buscamos, assim, compreender como se desenham as imagens do futuro da espécie humana no cinema. A pergunta que nos guiou ao longo do percurso foi: a partir das imagens que criamos hoje nos filmes de ficção científica sobre o amanhã, quais os desejos, os medos, esperanças, anseios e expectativas temos apontado em nossa construção coletiva do imaginário do futuro? Iniciamos pela perspectiva social de futuro que a publicidade no século 19 apontava para o ano 2000. Uma visão positiva de progresso a partir da tecnologia em nossas vidas. Em seguida, por meio de uma análisede uma constelação de frames de filmes futuristas contemporâneos, inspirada nos estudos do pesquisador Aby Warburg, propomos uma perspectiva de leitura e compreensão de uma memória social e seus respectivos afetos sobre as projeções contemporâneas de futuro do corpo humano. Neste momento podemos observar o pessimismo que as imagens traduzem da relação contemporânea das tecnologias com o corpo.

Palavras-chave: corpo humano; imaginário do futuro; cinema; ficção científica; Aby Warburg. 


\begin{abstract}
All that is solid melts into the future - imaginary perceptions of the body in futuristic movies - This paper investigates the projections of the social imaginary on the future of the human body in the cinematographic image of science fiction. We seek, therefore, to understand how images of the future of mankind play out in the movies. The question that guided us along the way was: based on the images we create today in science fiction films about tomorrow, which desires, fears, hopes, anxieties and expectations have we pointed out in our collective construction of the imaginary of the future? We started with the social perspective of the future that advertising in the 19th century pointed to for the year 2000. A positive view of progress from the technology in our lives. Then, through an analysis of a constellation of frames from contemporary futuristic films, inspired by the studies of the researcher Aby Warburg, we propose a perspective of reading and understanding of a social memory and its respective affects on the contemporary projections of the future of the body human. At this moment, we can observe the imagens reflect the pessimism in regard to the contemporary relationship between technologies and the body.
\end{abstract}

Keywords: human body; imaginary of the future; cinema; science fiction; Aby Warburg.

De fato, a predição nunca é neutra ou passiva. Corresponde sempre a uma intenção, a um desejo ou a um temor; exprime um contexto e um estado de espírito. A predição não nos esclarece sobre o futuro, mas reflete o presente. Nesse sentido, revela a mentalidade, a cultura de uma sociedade e de uma civilização.

George Minois

\title{
Introdução
}

Este artigo é resultado da pesquisa Futuros Humanos: a percepção do imaginário sobre humanos e cidades nos produtos midiáticos contemporâneos ${ }^{1}$. O estudo investiga as projeções do imaginário social sobre o futuro do corpo humano representadas na imagem cinematográfica da ficção científica. Buscamos, assim, compreender como se desenham as imagens do futuro da espécie humana no cinema. A pergunta que nos guiou ao longo do percurso foi: a partir das imagens que criamos hoje nos filmes de ficção científica sobre o amanhã, quais desejos, medos, esperanças, anseios e expectativas temos apontado em nossa construção coletiva do imaginário do futuro?

Os filmes trazidos para essa investigação abordam, em sua maioria, a temática de indivíduos que apresentam diferentes graus de hibridização de seus corpos com a tecnologia; desde pequenas extensões robóticas até trocas

1 Essa pesquisa foi financiada pelo programa Pibic-CNPQ (2018-2020). 
completas para um corpo artificial. São todos formas ciborgues, como pode ser observado nos filmes Monstro de Nova lorque (The Colossus of New York, 1979), Galaxy Express 999 (1979) e O Fantasma do Futuro (Ghost in the Shell, 1995). Também foram incluídas obras que abordavam a interação do corpo através da tecnologia para uma existência extrafísica, tema discutido em filmes como Matrix (1999) e O Passageiro do Futuro (The Lawnmower Man, 1992), nos quais a expressão de uma nova corporeidade plugada surge a partir da vivência psíquica em ambientes virtuais. Foram incorporadas também obras nas quais a tecnologia transforma quimicamente o orgânico e possibilita novas configurações com o inorgânico, como ocorre em Akira (1988), bem como obras em que a fusão orgânico/inorgânico inicia-se desde o processo embrionário por meio da manipulação genética, apresentados, por exemplo, em filmes como Blade Runner (1982) e Gattaca - Experiência Genética (1997).

Durante a primeira etapa metodológica do estudo, foi realizado um levantamento histórico de filmes, levando em consideração o impacto das obras à época de seus lançamentos, e suas repercussões ao longo do tempo. No total, foram elencados 167 filmes. A intenção nessa etapa da pesquisa foi identificar processos de recriação do humano física e cognitivamente, observando tipos de hibridismo, tipos de criação de formas humanoides, e de mecanismos de humanização de máquinas, bem como a emergência de novas subjetividades desses processos. Esse levantamento nos conduziu a um outro momento em que procuramos compreender as sensações, emoções e sensibilidades que os filmes apresentam diante dos conflitos de identidade, questionamentos existenciais, exclusão social e não pertencimento, dilemas éticos expostos pelos personagens.

Durante o processo de assistir aos filmes, algumas sequências ou até mesmo frames de cenas nos faziam lembrar de sequências ou frames de outros filmes, como se houvesse uma certa correspondência temática, ou de emoções ou de pathos provocando correspondências. Seguindo a ideia de uma imagem que evoca outra, experimentalmente foi posto em prática o conceito de pathosformel, de Aby Warburg (MICHAUD, 2013). A pathosformel ou a fórmula de pathos é um conjunto de expressões emocionais atemporais que nessa pesquisa foi usado para identificar conjuntos diferentes de sequências e imagens, em diferentes filmes, que evocam situações ou emoções similares.

Esse dispositivo experimental de reunião de imagens que se aproximam por camadas ou pathos de expressão e que atravessam vários filmes tornou-se um guia metodológico para observar e compreender como esses filmes dialogam entre si. Há uma profunda relação temática, seja através 
de gestos, diálogos e tramas, que de alguma maneira desenham as imagens do futuro da espécie humana nos tempos atuais. Esses filmes são reflexo do imaginário de cada momento em que foram concebidos e esse imaginário emerge, por sua vez, das forças coletivas que apontam quadros de expectativas, ansiedades, medos, desesperos, dúvidas, raiva e tantas outras emoções que se elaboram na experiência de futuro. Portanto, olhar para as projeções de futuro, principalmente às recriações de corpos humanos, é também um exercício de observar, no contemporâneo, como a sociedade lida com as transformações que ela mesma fomenta sob um discurso progressista o impacto dessas intervenções na vida humana e de todos os seres vivos.

\section{Rascunhos sobre o novo mundo}

Durante a Feira Mundial de Paris em 1900, a fábrica de chocolate alemã Theodor Hildebrand \& Son tomou os ares futuristas como inspiração para sua campanha comercial. Segundo Pauline de Tholozany (2011), tais eventos eram caracterizados pelo otimismo e entusiasmo sobre o progresso tecnológico e o ideal de uma comunidade universal, uma vez que diversos países europeus compartilhavam trabalhos artísticos e itens produzidos pelas indústrias. Sob o título Alemanha nos anos 2000, a Hildebrand ilustrou 12 cartões abordando a sociedade alemã no século 21 impressos nas caixas de seus produtos.

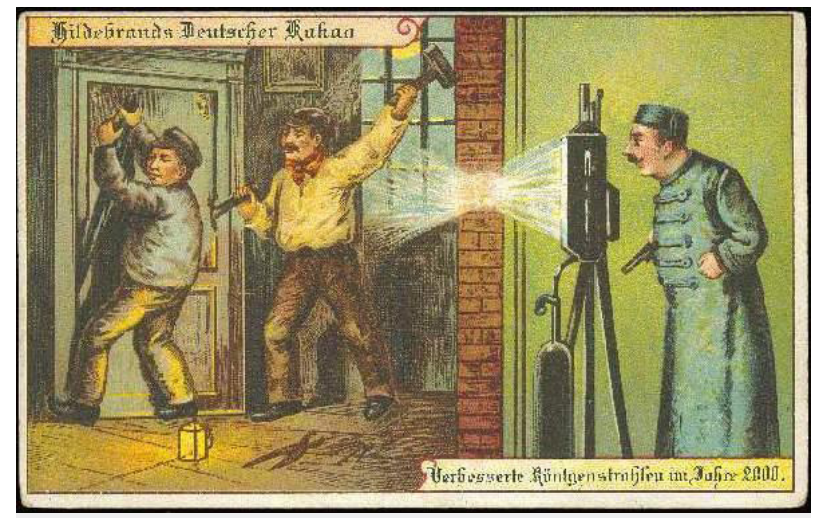

Figura 1. Policial usando o "pré-TV" (espécie de raio X). Alemanha, Fábrica Hildebrand. Fonte: Domínio Público (1900).

Na figura 1, o policial observa, por meio de um aparelho capaz de enxergar através das paredes, a tentativa de dois homens de arrombar uma porta. O policial, antes mesmo de mirar sua arma já em punho ou executar qualquer 
outra ação, parece tranquilo, como quem tem todo controle de uma situação. Os homens são observados sem saber, antecipando o desejo de vigilância onisciente dos séculos 20 e 21, no qual, em qualquer lugar, podemos estar sendo monitorados e vigiados por câmeras quase invisíveis.

Nas peças ilustradas da Hildebrand, os meios de transporte do futuro trazem uma adaptação dos meios utilizados no final dos novecentos, com arranjos científicos mirabolantes que modificam completamente a paisagem urbana futurista. Nas figuras 2 e 3, a partir dos gestos em destaque, vemos a naturalidade com que os personagens usufruem das novas tecnologias de transporte. A tecnologia e a ciência estão integradas positivamente, desvelando um novo mundo, sem hesitação ou medo. As mudanças foram harmoniosamente incorporadas no estilo de vida da sociedade dos anos 2000 e podemos perceber a expectativa de futuro que o imaginário social do final do século 19 trazia sobre o século 20. A partir desses registros, podemos identificar a apresentação de sentimentos e reflexões sobre as transformações de espaço e tempo, algo que vai além das fabulações do discurso publicitário.

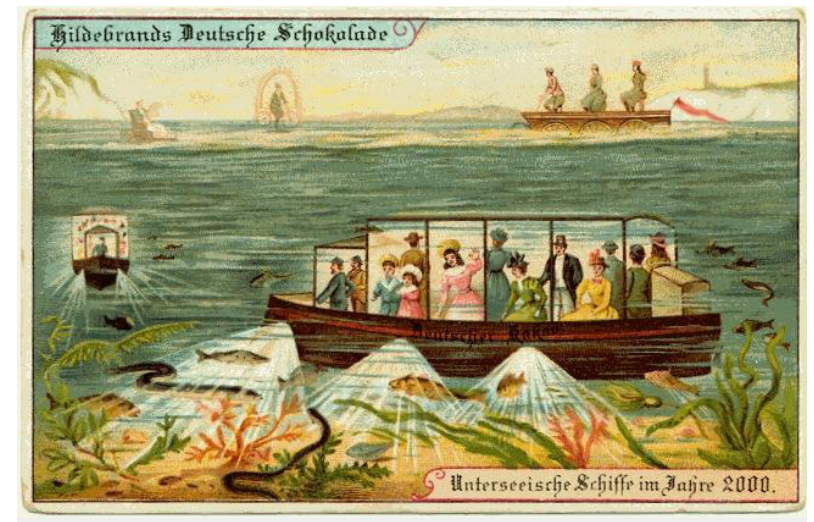

Figura 2. Viagens submarinas. Alemanha, Fábrica Hildebrand. Fonte: Domínio Público (1900).

Na figura 3, que vem a seguir, temos crianças, casais e até um cavalo caminhando sobre a água, como uma atividade cotidiana. A ideia de caminhar sobre as águas faz alusão a um poder divino que pode ser reproduzido pela ciência. O homem equivale-se a Deus e faz da narrativa de um milagre um comportamento cotidiano na paisagem social urbana do futuro. Essa mesma ideia de uma capacidade sobre-humana que pode ser atingida pela 
tecnologia também está na figura 2, acima, com a manifestação de uma curiosidade colonizadora sobre o fundo do mar e o vasto leque de criaturas desse ecossistema, assim como o desejo de dominar essa realidade e neutralizá-la, ao ponto de torná-la um espaço turístico.

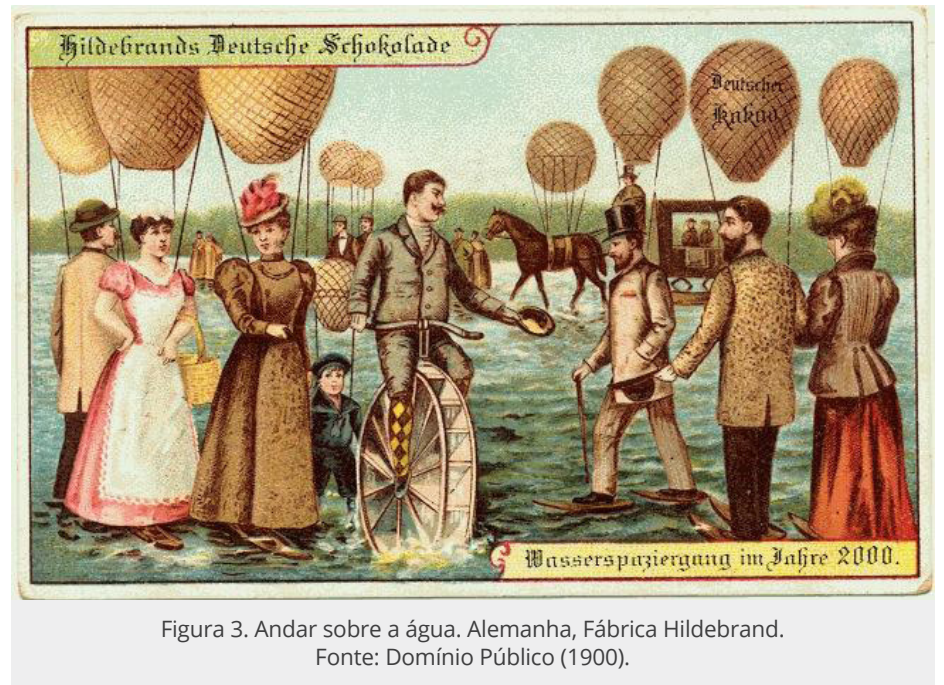

As imagens da Hildebrand são peças publicitárias para vender chocolates, mas é através dessas amostras simples, produzidas no cotidiano de uma época, que se consegue sentir sua forma de pensar no tempo. Quando hoje, a partir deste momento em que estamos, observamos o que se esperava na virada do século 19, temos o forte impacto do efeito do imaginário de cada época. Ao nos relacionarmos com tais ilustrações, somos introduzidos na representação de futuro realizada há mais de um século e entramos em contato com reverberações, ecos de impulsos latentes em um imaginário que, de alguma forma, se choca com o que somos hoje, em pleno século 21, e com nosso imaginário futurista. Por mais lúdicas e fantásticas que possam parecer, essas figuras do final do século 19 projetam vontades, desejos e uma real percepção de futuro como uma miragem distante, mas feliz.

Observemos agora um outro grupo de imagens de uma década anterior às ilustrações da fábrica alemã e que seguiam o mesmo conceito futurista de projetar a vida em sociedade nos anos 2000: 


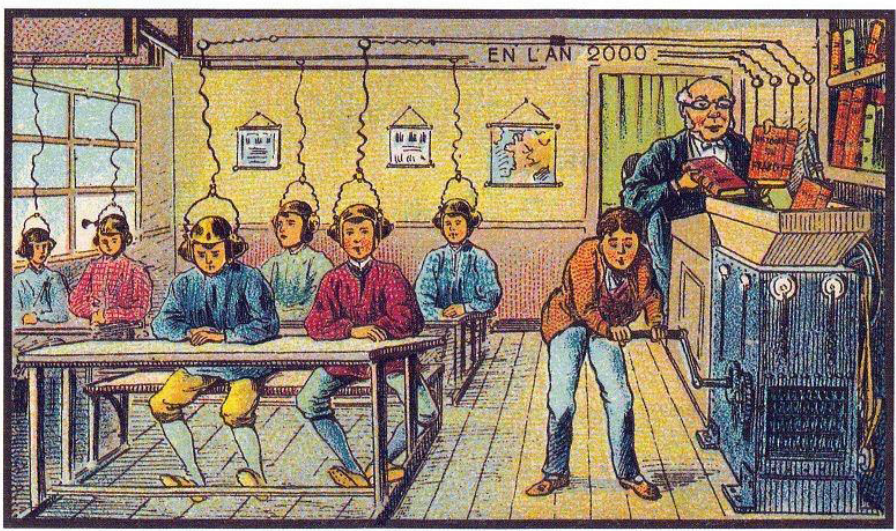

At School

Figura 4. Na escola, por Jean-Marc Côté. Fonte: Domínio Público (1899).

Em 1899, o francês Jean-Marc Côté, em conjunto com outros artistas, elaborou ilustrações para caixas de cigarro com o tema França no Século XXI. O projeto nunca foi lançado devido a complicações com a empresa financiadora. Um total de 86 ilustrações contendo o trabalho de Côté e de outros desenhistas veio a público pela primeira vez em 1986, com a publicação da obra Futuredays: A Nineteenth Century Vision of the Year 2000, por Isaac Asimov (MILLS, 2015).

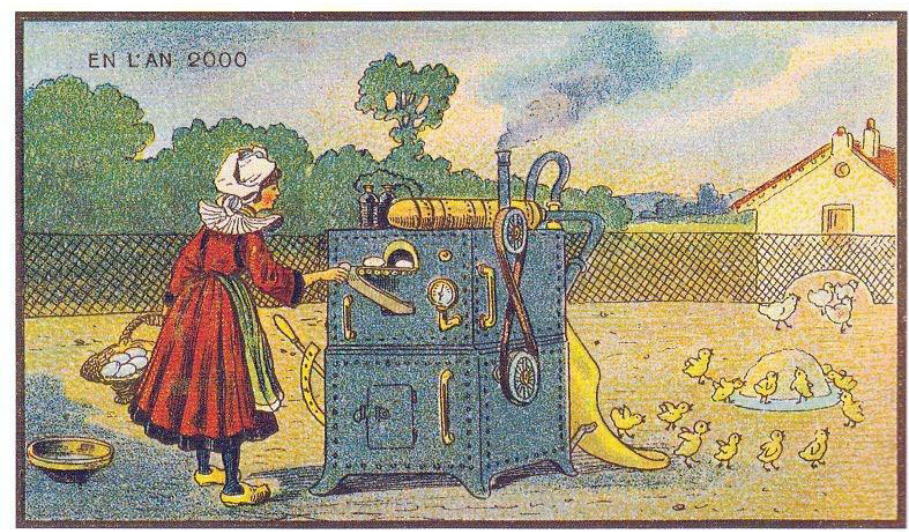

Intensive Breeding

Figura 5. Reprodução intensa, por Jean-Marc Côté. Fonte: Domínio Público (1899). 
Assim como os cartões da Hildebrand, vemos imagens que apresentam o dia a dia tecnológico do futuro. Podemos observar que, tanto na escola quanto na criação de animais, o sistema de processamento tecnológico acelera e otimiza a vida das pessoas. Na figura 4, os estudantes têm seu aprendizado otimizado por uma máquina que realiza uma espécie de download das informações dos livros diretamente em suas mentes. Na figura 5, uma máquina choca os ovos instantaneamente e acelera o nascimento dos pintos, sem que seja necessário esperar seu tempo natural para romperem as casas. A expectativa claramente aponta o desejo de que a tecnologia agilize, no futuro, processos naturais do cotidiano.

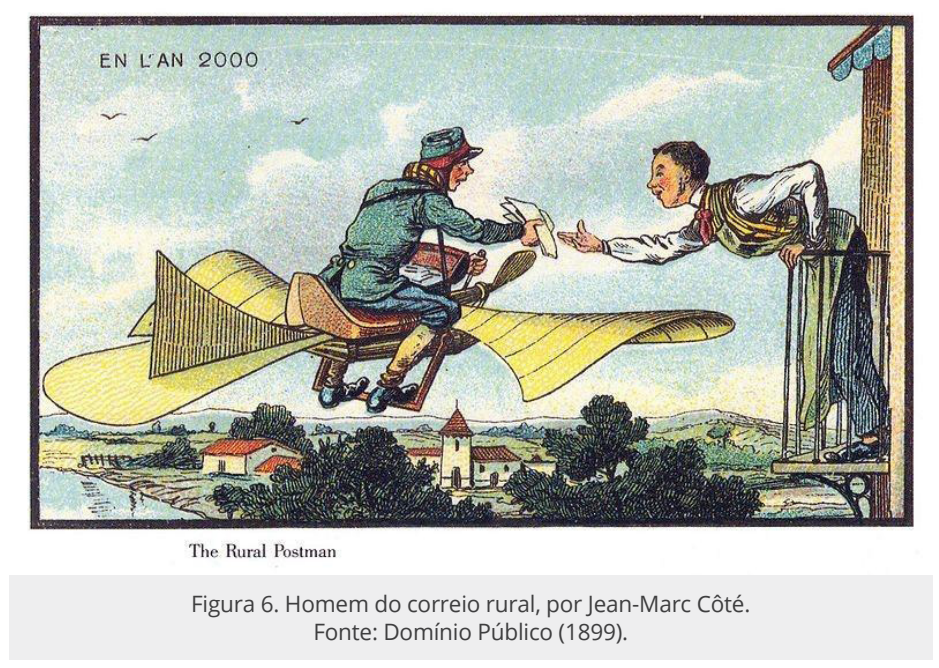

Por mais absurdas que sejam as situações imaginadas nos dias de hoje, a imaginação do futuro permite, em suas imagens fantasiosas, misturar a brincadeira com o sonho das possibilidades das tecnologias dominarem a natureza. O carteiro rural atravessa os céus pilotando um veículo aéreo e entrega suas correspondências em domicílio, como na figura 6, enquanto que, numa nova modalidade de pescaria invertida, mergulhadores "pescam" gaivotas de dentro d'água. O enquadramento dado por Côté nessas peças ilustra o desejo humano de expandir suas limitações; percebe-se a necessidade de ultrapassar habilidades físicas como voar, respirar debaixo d'água e ter controle sobre outras espécies, absorvendo pela tecnologia as características de aves e peixes. Expandir as habilidades do corpo humano por meio do conhecimento técnico. 


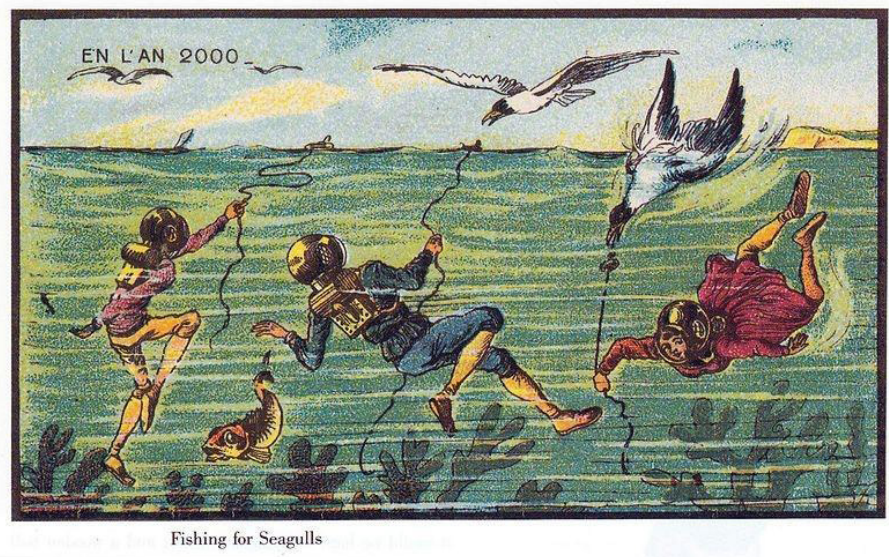

Figura 7. Pescando gaivotas. Fonte: Domínio Público (1899).

Nessas obras, percebemos como a ficção científica inspira, e também revela, a construção de narrativas repletas de expectativas, perspectivas, desejos de uma época condensados no simples exercício de pensar a partir de imagens. Além do desenvolvimento de um discurso futurístico, vemos nessas peças a ambição da humanidade por criar um caminho na direção deste futuro, por meio das tecnologias.

Entretanto, o que as imagens de hoje, em pleno século 21, pensam sobre nosso futuro? No espaço de tempo de cem anos, as perspectivas e expectativas sobre o futuro mudaram drasticamente. Os acontecimentos de um século refundaram o imaginário de futuro contemporâneo, mostrando claramente que toda ideia de um futuro é fruto de um presente (MINOIS, 2015).

\section{Montagens de imagens sobre o imaginário do futuro}

Tomamos a intuição das montagens de pranchas de imagens desenvolvidas por Aby Warburg, em seu Atlas Mnemosyne, como auxílio para pensar numa proposta de método que nos permitisse conhecer algo desse imaginário de futuro contemporâneo. Tanto o modo de coleta do material imagético como a montagem do Atlas partiram de uma perspectiva na qual Warburg percebia uma grande força simbólica, intelectual e emotiva que emergia na Antiguidade Ocidental e, posteriormente, reaparecia e era reanimada na arte e na cosmologia de tempos e lugares (JOHNSON, 2012). Warburg utilizava esses painéis para mapear o trajeto das fórmulas de pathos que se 
desenhavam nessas imagens, que ressurgiam em diferentes manifestações culturais, e de aspectos que sobreviviam na memória coletiva porque, de acordo com sua abordagem, as imagens operavam como dinamogramas, "campos de forças sociais e culturais" (MACIEL, 2018, p.191).

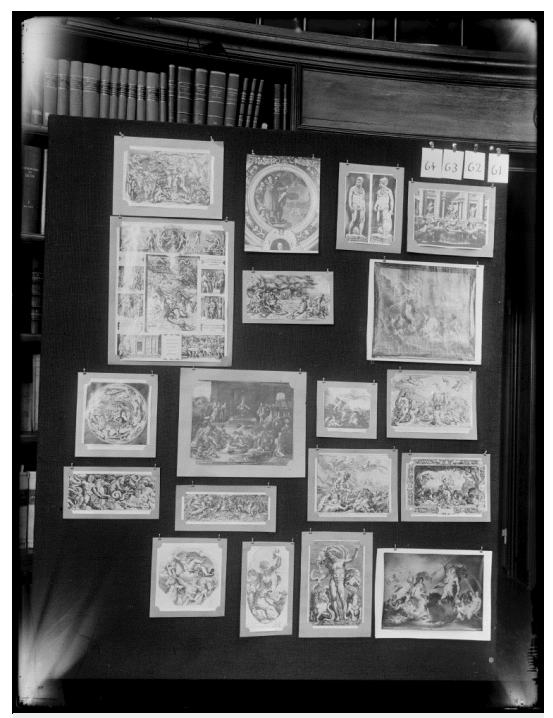

Figura 8. Pranchas 61-64 do Atlas Mnemosyne. Fonte: Cornell University Library.

Com o Atlas, "Warburg elaborou um modo de produção de saber cujos argumentos são formulados e desenvolvidos pelas próprias imagens quando relacionadas, uma perspectiva que promovia a ativação das forças nelas contidas" (MACIEL, 2018, p. 192).

[...] o grande esforço dessa proposta está na disposição para articular uma outra dimensão epistêmica. Esse empreendimento deve obedecer a uma espécie de meditação da imanência, da presença, da força produtora de um conhecimento que ativa-se nas lacunas entre as imagens. Isso é o que se quer dizer por pensar por imagens, pôr imagens lado a lado para sentir se ressoam aspectos, gestos e emoções comuns. Trata-se de ler o que não está escrito, mas que se pode apostar existir como uma intuição afetiva atemporal (DUARTE; SEVERIEN, 2018, p. 220).

Desta forma, tanto a montagem quanto o processo de leitura de uma prancha podem ser desafiadores, visto que eles sugerem uma abordagem que 
estimula o indivíduo a pensar por conjunção de imagens, indo além de uma compreensão analítica e comparativa. Em outras palavras, uma perspectiva que busca pensar as imagens agindo em contiguidade, umas com as outras. Como um processo de ativação recíproca, cada elemento detém um potencial de ressonância que, ao ser estimulado, devolve simultaneamente o estímulo, fazendo emergir uma zona de entendimento comum entre as imagens. No caso das pranchas, quando as imagens se encontram, elas ativam uma dinâmica própria de contingência de sentido, atraindo outras imagens que, de alguma forma, se relacionam e possibilitam a construção de sentidos de compreensão em comum (DUARTE; SEVERIEN, 2018, p. 211-212).

Como apresentado na introdução deste artigo, muitos filmes foram vistos ao longo da pesquisa, no esforço de encontrar essas reciprocidades entre imagens com o objetivo de gerar ideias quando vistas lado a lado, para que pudéssemos pensá-las em constelações. A partir da busca por emoções que compõem um imaginário de futuro, elaboramos uma montagem em formato de painel, semelhante às pranchas pensadas por Aby Warburg, no Atlas Mnesmosyne. Esse é um dos vários caminhos possíveis para se relacionar com essas imagens. Ao todo, construímos oito painéis mas para este artigo, vamos tentar explorar as impressões de uma dessas pranchas. Fomos tocados inicialmente por uma forte sensação de solidão e desespero que a ideia de fusionamento dos corpos humanos com as tecnologias apresentava dos personagens. A tecnologia, nesses filmes, não traz qualquer sensação de acolhimento da condição humana. As máquinas alteram violentamente a percepção ontológica que o humano tem sobre a humanidade que ainda Ihe resta.

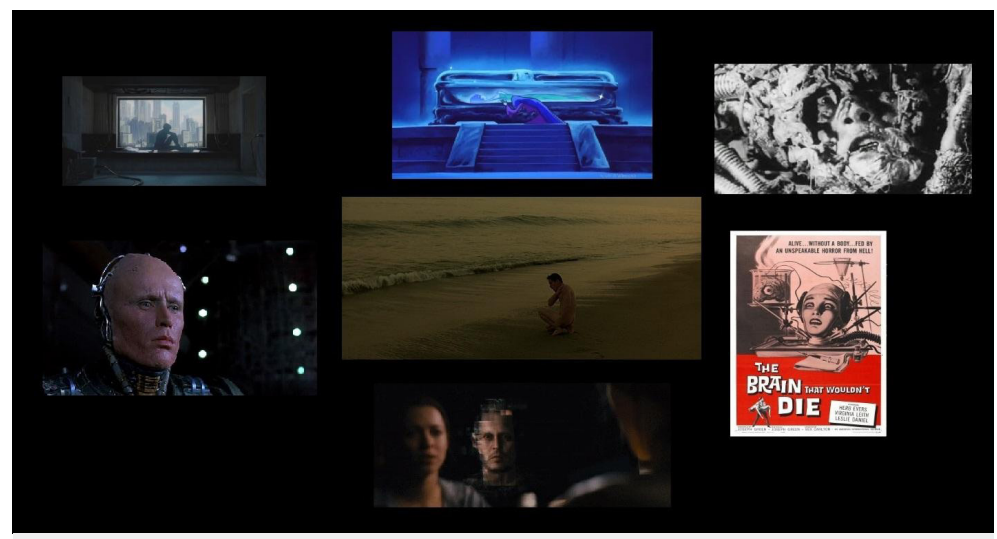

Figura 9. Prancha a recriação do corpo humano no futuro. Fonte: frames dos filmes compilado pelos autores. 
Nessa prancha, expusemos frames de diferentes obras cinematográficas que se atraem pela sensação de desconforto físico ou mental gerado pela imposição, mutação, perda ou reconfiguração de uma identidade, que aqui é compreendida como a capacidade que um indivíduo possui “de reivindicar uma vida interior: ter razões e opiniões próprias, motivações existencialmente definidas, paixões pessoais, e traços de uma essência" (GERGEN, 1996, p. 128).

A pathosformel da perda de si manifesta-se tanto fisicamente quanto psicologicamente, como uma violência simbólica corroendo o indivíduo contemporâneo de dentro para fora.

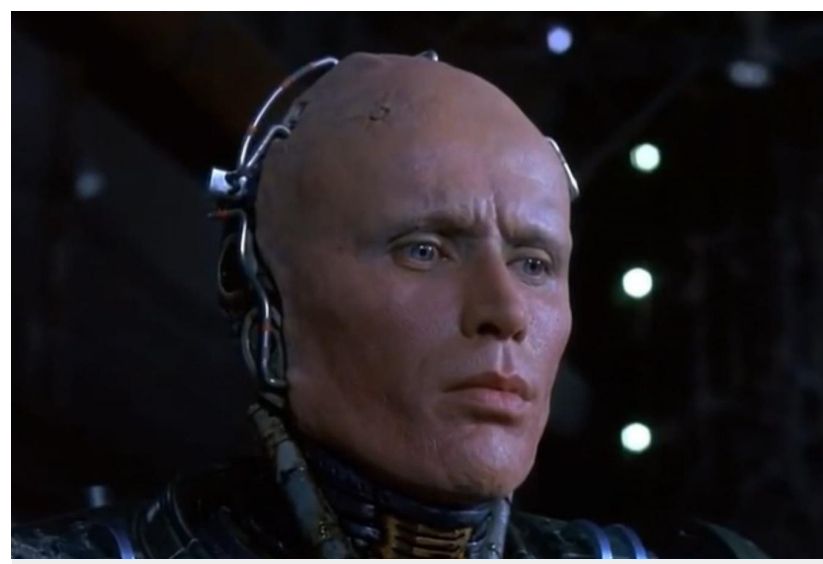

Figura 10. Robocop - O Policial do futuro. Frame "1:21:54" de "1:42:46".

O quadro fílmico em destaque foi retirado de Robocop - O Policial do Futuro (1987), obra policial e de ficção científica dirigida por Paul Verhoeven que conta a história do policial ciborgue Alex Murphy, numa versão distópica da cidade de Detroit. Após ser atacado por uma gangue, Murphy é gravemente ferido e considerado morto. Com o objetivo de eliminar a criminalidade da cidade para a construção da utópica Delta City, o executivo Dick Jones sugere a implementação de um androide como pacificador urbano, o ED-209. Devido às falhas apresentadas pelo protótipo de Jones, Bob Morton apresenta o projeto Robocop, a união entre uma máquina e um policial como alternativa para solucionar o problema da violência urbana.

Após o episódio de quase morte, as partes restantes do corpo do personagem principal foram levadas para a construção do primeiro protótipo do projeto. Murphy teve seu corpo remontado por terminações cibernéticas, e 
sua memória aparentemente apagada e reprogramada para atuar na segurança pública. A cena do filme disposta na prancha traz o instante em que Murphy é apresentado ao seu novo eu, olhando-se no espelho. O personagem teve toda sua corporeidade manipulada sem escolha, assim como sua mente, que já não operava normalmente devido à incorporação de um programa controlando sua consciência, interferindo na forma como ele percebia ambientes e as outras pessoas.

Apesar das tentativas do sistema de apagar o que restara de humanidade ao Robocop, algumas lembranças dele resistiam, como momentos em família, assim como o episódio de violência que ele sofreu. As emoções não podiam ser reprogramadas como o corpo de Murphy. No instante em que o ciborgue se depara com seu reflexo e aproxima a mão mecânica do rosto, percebe-se que o seu olhar permanece congelado, sem qualquer identidade com aquele corpo. Surge uma sensação de vazio existencial, um buraco de não identificação entre o indivíduo e sua própria imagem.

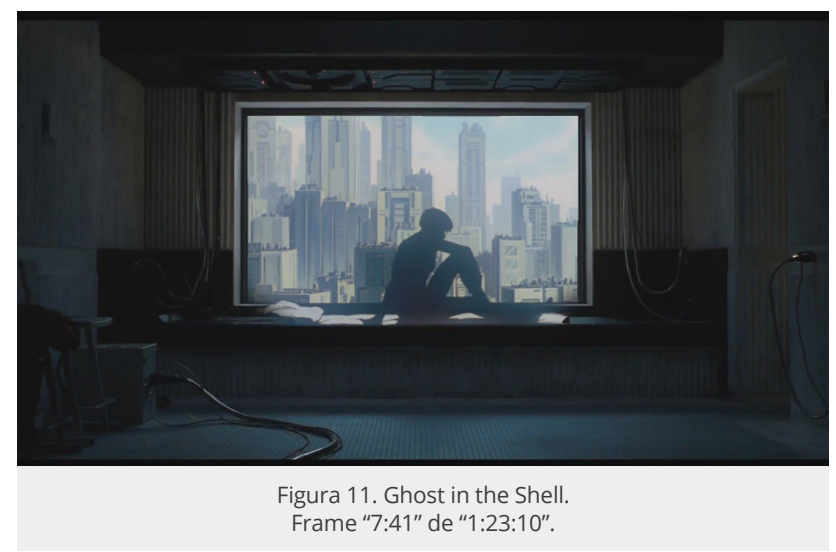

Fomos então levados à imagem seguinte, tocados por esse frame do filme $O$ Fantasma do Futuro (Ghost in the Shell, 1995). Um plano aberto traz ao centro o vulto solitário de uma pessoa em contraluz, numa janela, tendo ao fundo um ambiente urbano. A silhueta expõe um gesto que, no contexto do filme, mobiliza a sensação de uma solidão voluntária, um desejo de isolar-se das pessoas. Nessa imagem, a pathosformel da perda de si apresenta uma outra faceta desse processo: o de lidar com uma nova existência, o momento em que o indivíduo procura em si mecanismos de forjar um novo eu. Eis o motivo que levou a policial a isolar-se: ela tenta remontar algum sentido entre seus resquícios de memória e sua condição atual. 
No limiar entre os dualismos homem e máquina, assim como corpo e alma, encontra-se Major Motoko Kusanagi, a ciborgue protagonista da série de mangás The Ghost in the Shell (1989)². O sentimento partilhado aqui não diz respeito à perda de algo diretamente, mas a de uma lacuna existencial que o personagem vai se dando conta, a partir do conflito entre a percepção precisa e racional da inteligência artificial em seu cérebro com seu lado humano.

No universo transhumanista criado por Shirow, as mentes humanas estariam livres para transitar no ciberespaço, conectando seus pensamentos com outros cérebros por meio de redes, assim como realizar um mergulho na mente de outros indivíduos para compartilhar suas memórias e emoções. Um futuro em que a mente é completamente descolada do corpo, o fantasma é despreendido de sua casca por mecanismos cibernéticos. A história acontece no ano de 2029 e é contada pela perspectiva de Kusanagi, agente cibernética da Section 9, uma espécie de agência responsável pela segurança nacional, que está numa operação contra o Puppet Master, o criminoso responsável por hackear cérebros cibernéticos de cidadãos, inserindo memória fictícias para controlá-los.

Mesmo após os processos de intervenções e aprimoramentos tecnológicos em seu corpo, algum aspecto mental de Motoko ainda sobrevive e cria mecanismos para lidar com as transformações que ela enfrentou. No caso de Ghost in the Shell, tanto no mangá como no filme, não há uma relação de disputa entre homem e máquina, mas uma síntese entre as polaridades que compõem Motoko, formando um ser híbrido. O mal-estar experienciado pela personagem parte de um lugar de descoberta e entendimento de uma identidade ciborgue em construção, a reconfiguração de uma nova essência forjada no encontro do orgânico e o artificial.

Ao definir o corpo humano no século 17, o filósofo René Descartes estabeleceu analogias com máquinas hidráulicas, relógios e autômatos ao chamar a anatomia humana de corpo-máquina. O pensador reconhecia corpo e mente como substâncias distintas, porém complementares na formação do homem. Apesar de não compreender o funcionamento desses componentes, o pensador francês percebeu a existência de uma substância imaterial no cérebro, essencial para a construção do homem, o "penso, logo, existo" (SIBILA, 2014, p. 74-75). 
Na narrativa de Ghost in the Shell, esse elemento imaterial poderia ser representado pelo fantasma; em outras palavras, a alma do indivíduo, o fator que determina a identidade de um sujeito, o que o distingue de uma máquina. No entanto, contrária à perspectiva de Descartes, o corpo nesta obra fílmica é apenas um rascunho, algo a ser manipulado ou até mesmo ultrapassado, deixando de ser um elemento essencial na formação de um indivíduo, mas o reflexo de uma linha de pensamento que visa ao progresso acima de qualquer custo.

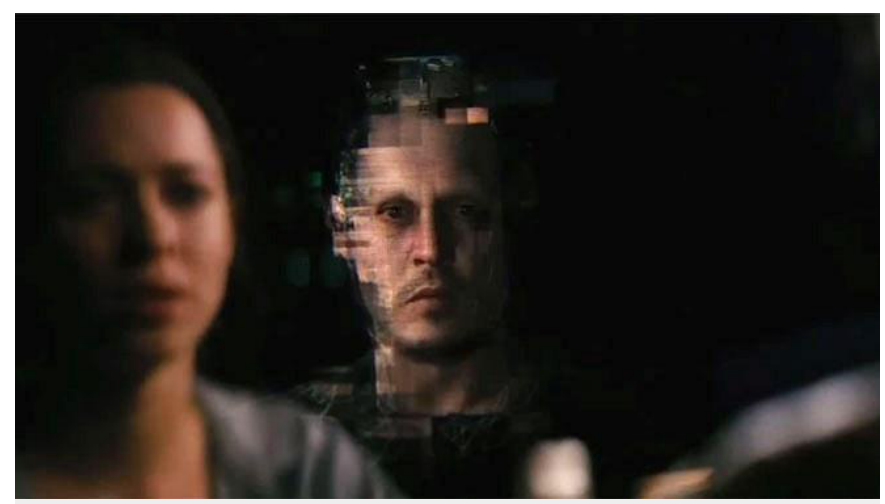

Figura 12. Transcendence - A Revolução. Frame "39:13" de "1:59:16"'".

Na imagem anterior (Figura 12) vemos, lado a lado, um rosto humano refletido num espelho desfocado e outro distorcido por pixels. A imagem do Dr. Will Caster surge de forma seca, com um aspecto enrijecido, trazendo uma forte sensação de vazio, o que nos lembra o Robocop, comentado anteriormente. O primeiro contato visual parece não afetar Dr. Will, mas choca a sua esposa. Ela, ao contrário de Will, está profundamente emocionada por dialogar com o upload do seu marido no ambiente virtual.

Em Transcendence - A Revolução (2014), há um contraste entre dois pontos de vista em relação aos caminhos que o futuro da tecnologia guarda para a humanidade. De um lado, os pesquisadores que defendem o desenvolvimento da Inteligência Artificial a qualquer custo. De outro, os que problematizam os impactos desses avanços, ou seja, o tradicional embate homem versus máquina. Em determinado momento da história, o Dr. Will Caster, um dos cientistas mais proeminentes dos estudos de criação de uma superinteligência artificial, sofre um ataque de movimentos extremistas contrários a essa tecnologia. Will é envenenado por uma substância letal 
e vê como única saída realizar o upload de sua consciência para o mundo virtual, utilizando o software criado por ele. Assim, desenvolve-se uma nova identidade que se constitui a partir dos padrões neurais do cientista, como suas memórias e sentimentos, e o programa de inteligência artificial.

O momento do filme escolhido para a prancha retrata o instante em que Evelyn Caster, esposa e pesquisadora auxiliar de Will Caster, tem o primeiro contato com o fantasma virtual do seu marido, enquanto se observa refletida numa tela. Vemos, na figura 12, como o impacto da pathosformel da perda de uma identidade reverbera para outras pessoas, além do ser que passa por essas transformações. O sofrimento também é partilhado por aqueles conectados com esses indivíduos híbridos com o tecnológico. Talvez essa seja uma das imagens mais empáticas da prancha, uma vez que percebemos que há uma presença humana em meio a tantas imagens ciborgues, o que possibilita ao espectador entrar por uma brecha, participando da mesma situação. Algo é de contraste brutal nessa imagem: no mesmo enquadramento, traz uma mulher viva que encara um homem fisicamente morto mas aparentemente vivo.

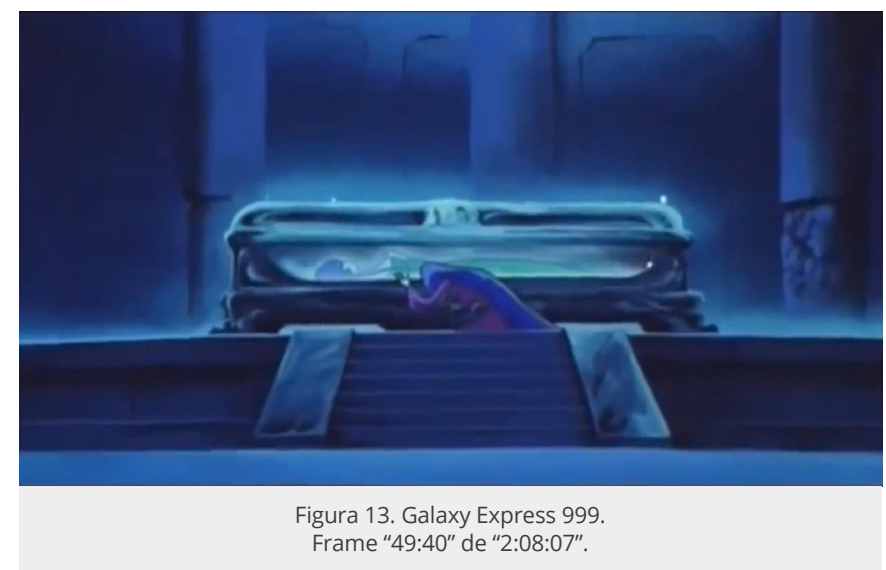

O morto e o vivo chamam a melancolia nostálgica de nossa próxima imagem. A personagem retratada na figura 13 chama-se Shadow e é uma guardiã do cemitério dos corpos de todos que abandonaram a sua humanidade por opção, no filme Galaxy Express 999 (1979). Shadow vive num contínuo estado de luto e arrependimento pela escolha tomada e permanece em Plutão para velar seu antigo corpo humano. Aqui, de forma semelhante aos outros filmes, o diretor Rintaro apresenta uma perspectiva de futuro na qual a noção 
de humanidade se perde com os processos de hibridização entre homem e máquina, passando a viver numa condição melancólica, com saudade de si mesmo, desejando congelar no tempo e no espaço uma versão de algo que não existe mais.

Na trama, o corpo humano tornou-se obsoleto devido à transferência da consciência humana para corpos robóticos. Tal procedimento é vendido para a classe alta da sociedade sob a premissa de uma vida eterna, o próximo passo a ser dado para a evolução da espécie. Entretanto, uma vez que esses indivíduos abdicam de seus corpos e ultrapassam a morte, lentamente deixam de valorizar a vida, o que os torna criaturas perversas e sádicas. Ou seja, neste anime, a medida do valor à vida era a certeza da morte. Se a morte não é mais uma certeza, a condição humana se perverte contra si mesma. Os que ainda continuaram com o corpo orgânico vivem sendo caçados como animais e presos às condições sub-humanas nas periferias da capital, localizada no planeta Terra, a Megalópoles.

O motivo da escolha de um corpo robótico sem expressões faciais é que o antigo rosto de Shadow se tratava de um dos mais lindos que a ciborgue conhecera.Aqui, a face é tratada pela personagem como um aspecto de sua humanidade a ser preservado. Conforme Le Breton, o rosto é uma das partes do corpo humano em que se cristalizam os sentimentos do indivíduo a respeito de sua identidade.

Numerosas são as tradições nas quais o rosto é associado a uma revelação da alma. [...] O valor ao mesmo tempo social e individual que distingue o rosto do resto do corpo, sua eminência na apreensão da identidade é sustentada pelo sentimento que o ser inteiro aí se encontra. (LE BRETON, 2017, p. 70-71).

Em O cinema ou o homem imaginário - Ensaio de Antropologia Sociológica, Edgar Morin (2014) evidencia a capacidade que o cinema tem de promover a identificação da plateia com os personagens dos filmes. Em outras palavras, o autor reconhece a relação subjetiva de representação e identificação do espectador com o conteúdo das imagens cinematográficas. Ao descrever mais a fundo o fenômeno dessa participação afetiva, Morin (2014) destaca o uso dramático do close-up, ou seja, do primeiro plano, como um mecanismo que permite que o espectador insira no rosto dos personagens suas projeções-identificações: 


\begin{abstract}
O rosto se tornou um médium. Epstein dizia, muito acertadamente, que o close é 'psicanalítico'. Ele nos faz redescobrir o rosto e permite que leiamos nele - essa é a grande ideia de Balázs em Der Sischtbare Mensch. Mergulhamos nele como num espelho onde aparece a raiz da alma, seu fundamento. A grandeza de Griffith e Pudovkin foi relevar, quase radiograficamente, que esse fundamento era o cosmo: o rosto como espelho da alma, e a própria alma como espelho do mundo. O close vê bem mais que a alma na alma; ele vê o mundo na raiz da alma. (MORIN, 2014, p.134).
\end{abstract}

Os primeiros planos apresentados na prancha transmitem uma tentativa de rastro da alma de seus personagens. Esses sentimentos constituem um portal para a humanidade dessas imagens com maior empatia. A pathosformel partilhada une as imagens pela dor das pessoas ao imaginar seu corpo sendo permeado por intervenções tecnológicas, uma conexão que se dá por meio das diferentes formas de expressão.

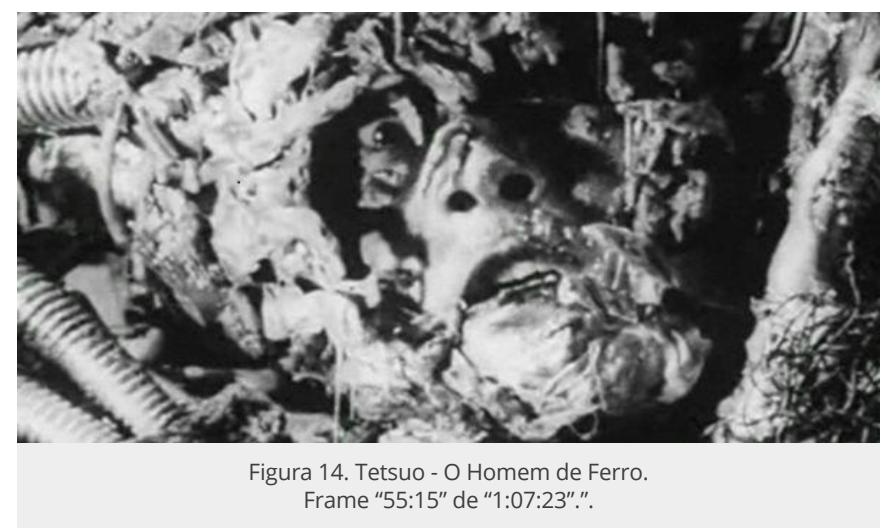

Alguns corpos dessa prancha passam por intervenções tecnológicas que nem sempre são tratadas sob a ótica asséptica da ciência. O filme japonês Tetsuo - O Homem de Ferro (1989), de Shinya Tsukamoto, aborda o universo cyberpunk a partir do subgênero do horror conhecido como body horror. O filme de Tsukamoto narra o conflito entre dois personagens, o metal fetichist, que introduz partes de metal em seu corpo numa tentativa de tornar-se máquina, e um trabalhador comum japonês (MOORE, 2019). Num determinado momento, o trabalhador acidentalmente atropela o fetichista e tenta se livrar do corpo. Como punição, o jovem é transformado aos poucos em ciborgue, sendo contaminado por uma espécie de doença que funde seu corpo com metais. 
A cena recortada para a prancha, na figura 14, explora, exclusivamente pelo close, um rosto aflito e todo o desconforto vivido pelo personagem que já não tem mais controle sobre a situação, já que seu corpo se encontra numa simbiose desenfreada com a máquina. O próprio filme constrói uma atmosfera monstruosa e perturbadora, com uma trilha sonora marcada por sons metálicos e industriais, acompanhada de ações frenéticas e impulsivas por parte dos personagens, como se o próprio filme agonizasse junto com os corpos ali em hibridização. Diferentemente da abordagem Ocidental sobre o gênero cyberpunk, mais voltada para o homem e o ciberespaço, os orientais apresentam discussões mais recorrentes a respeito da fusão entre carne e metal, com um estilo marcado por ambientes urbanos, personagens marginalizados e poluição sonora (BATARCE, 2011).

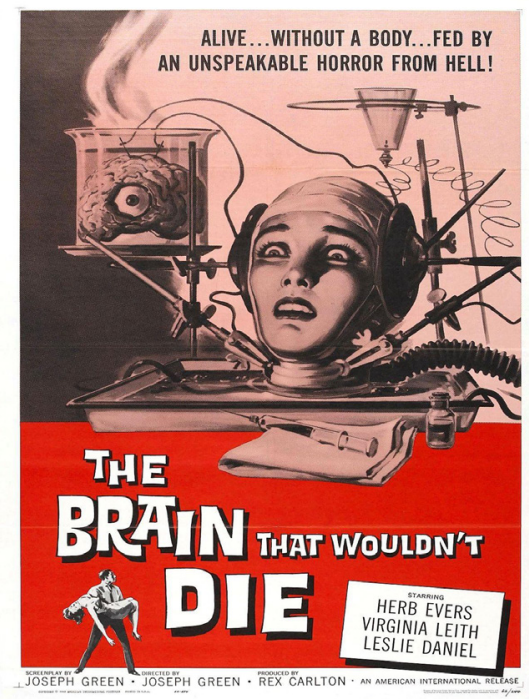

Figura 15. O cérebro que não queria morrer. Fonte: via wrongsideoftheart.com.

Seguindo a vertente dos afetos relacionados ao horror, o cartaz retirado do filme $O$ cérebro que não queria morrer (1962), dirigido por Joseph Green, compõe junto com Tetsuo uma polaridade energética na prancha de emoções, em que o contraste de identidade é dominado por rostos amedrontados, pela dor física e a sensação de desespero. Os traços faciais são mais expressivos e comunicam com maior clareza o horror do contexto. Essas duas imagens operam como dois pontos de pressão na prancha ao apresentar sentimentos 
tão crus e palpáveis em comparação com a subjetividade e introspecção de outras imagens, um jogo de polos opostos que acabam ativando uma contingência de afetos, como camadas da mesma pathosformel, adicionando o medo e a incerteza inerentes à existência.

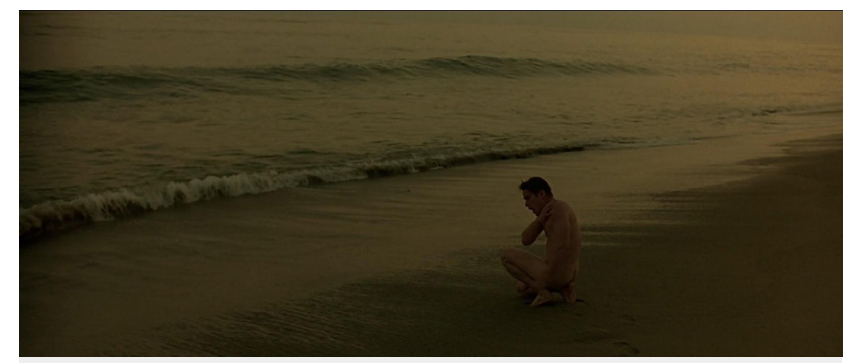

Figura 16. Gattaca - Experiência Genética. Frame "1:15:50" de "1:46:27"

Em meio a tantos corpos permeados por aparatos tecnológicos, o último quadro (figura 16) traz um homem nu, agachado numa praia, a céu aberto, numa madrugada. A vulnerabilidade e o medo das imagens anteriores nos trazem até aqui, num gesto e enquadramento oposto. Saímos do close aterrorizados, mas a condição de fragilidade atravessa todo esse conjunto da constelação.

Trata-se de uma cena do filme Gattaca - Experiência Genética (1997), obra de Andrew Niccol, narrada num futuro liderado por corpos manipulados geneticamente, em que indivíduos concebidos organicamente vivem à margem da sociedade, como é o caso do protagonista, Vincent Freeman. Chamados de "inválidos", essa parcela da população desenvolve um sentimento de revolta por seus corpos, rotulados de imperfeitos e falhos, vítimas de um erro da natureza.

Após envolver-se numa série de tentativas de camuflar seu DNA para usufruir dos privilégios de ser geneticamente modificado, Vincent corre o risco de ser exposto após passar a noite com Irene Cassini. A figura 16 remonta ao instante em que o personagem esfrega areia na pele para retirar fragmentos de pele seca que possam revelar sua identidade. Embora não existam próteses mecatrônicas no corpo de Freeman, já que ele foi concebido de forma sexual e sem manipulação do DNA, ele se auto rejeita, já que a sociedade o considera inferior. O personagem é triste, sempre desconfiado, parece não relaxar em momento algum por não acompanhar o estágio evolutivo 
de sua própria espécie, como um modelo ultrapassado de um projeto de humanidade que faliu.

O corpo de Vincent e toda vulnerabilidade de seu gesto perante o mar dissipam a pathosformel da perda e da reconfiguração de uma identidade humana pelos quatros cantos da prancha, o que retroalimenta a circularidade do pensamento que brota do movimento convulsivo entre essas imagens do imaginário futuro. Essa última cena poderia simbolizar o fim da leitura da prancha montada neste estudo ou apenas seu ponto de partida.

\section{Considerações Finais}

Os Australopitecíneos viveram há 3,1 milhões de anos. Os primeiros seres do gênero Homo viveram há 1,7 milhão de anos. O Homo antecessor viveu há 500 mil anos. O homem de Neandertal viveu há 255 mil anos. O Homo sapiens sapiens surgiu há apenas 150 mil anos (DUARTE, 2004). Observando esses registros, percebe-se que o processo de hominização foi se tornando gradativamente mais curto. Cada nova espécie teve um tempo cada vez menor de vida, tornando-se contemporâneo e logo sucedido por outro estágio de hominização, ainda mais curto. O fenômeno da hominização tornou-se cada vez mais rápido, as mudanças e acelerações culturais passaram a ser ainda mais velozes, no ritmo de infinitas complexificações tecnológicas e diversificações culturais.

O homo sapiens sapiens passou a ser a expressão mais bem definida da evolução dos hominídeos a partir da auto-organização com seus ecossistemas e com seu repertório tecnológico. Não só as mudanças do meio-ambiente, mas também cada ferramenta que virtualiza uma ação física interfere na reconfiguração do corpo em gerações futuras. Essa ação acelera-se na proporção em que crescem a dependência da técnica e a enxurrada de novas expressões tecnológicas. Cada nova expressão combina-se e soma-se com as anteriores, montando uma ampla teia de relações técnicas, que aos poucos fogem ao nosso controle.

Os cenários futuros de dissipação de nossa espécie têm sido apresentados, pela ficção científica, em imagens como a de máquinas com cérebro humano que sofrem crises de identidade por terem perdido parte da memória e não se reconhecerem no novo corpo que receberam, como no filme Robocop. Também os cadáveres de soldados que são quimicamente reanimados para se tornarem máquinas de guerra, mas que não resistem à elevação da temperatura durante suas missões, como os do filme O Soldado do Futuro. 
Ou a sofisticada combinação de engenharia genética e inteligência artificial dos replicantes, enviados para missões fora da Terra e que se rebelam contra o homem no desejo incontrolável de descobrirem o quanto podem viver, do filme Blade Runner. Ou os robôs carentes que aos poucos se descobrem seres conscientes, nos filmes O Homem Bicentenário e Inteligência Artificial, e os robôs enfurecidos que voltam ao passado para reescrever páginas de sua história, como no Exterminador do Futuro. Ou, ainda, os seres clonados ou manipulados geneticamente com seus conflitos e luta pela legitimidade de suas existências, nos filmes Gattaca e O Sexto Dia.

Percebe-se que o futuro, ou melhor, a imagem do futuro, emerge como uma intensificação do presente. A força de pressão simbólica das contingências do presente faz exalar um imaginário que dirige ao futuro sua projeção. Dessa forma, vimos que, no final do século 19, a aparição de novas invenções técnicas, o incremento das máquinas industriais, o surgimento dos automóveis, em seguida dos aviões e de tantos novos dispositivos, criaram a expectativa de que a tecnologia existia para facilitar a vida das sociedades. A grande máquina ruidosa era a imagem da tecnologia que mudaria o mundo (BERARDI, 2019). A tecnologia estava, naquele momento, sendo vista como algo exterior ao corpo humano, máquinas externas à mente e ao corpo. Elas apontavam promessas e sonhos de uma agilidade na realização de nossas atividades, que nos levaria a ter mais tempo livre para o lazer, a aumentar a produção de alimentos, a popularizar e a aumentar o alcance da formação e educação, entre tantos outros ganhos. Mas o futuro, quando ele existia, também trazia sua incerteza. No caso do futuro do século 19, este se concretizou em sua distopia, quando as máquinas passaram a viver dentro dos homens como sistematizadores da produção cognitiva e a recriação de novos corpos.

Imaginávamos que, no final do século 19, a intensificação tecnológica do presente ainda se colocaria como uma promessa que, de forma positiva, projetaria miríades de mundos imaginados. A intensificação do presente no final desse século trazia esperança, lançava a imaginação para horizontes possíveis com descobertas que alargavam a separação entre presente e futuro por força da imaginação criadora.

Entretanto, todos os cenários distópicos esboçados pelas mais diversas formas de ficção científica futurista ao longo do século 20, como destruição de recursos naturais do planeta, pandemias de vírus destruidores, poluição atmosférica, escassez de água, entre outros desastres naturais, começaram 
a se tornar realidades. O que nos parece é que se tornou impossível para a ficção científica contemporânea imaginar um futuro descolado da pressão imaginária desse presente. As especulações do futuro foram esmagadas pela dureza insana de uma realidade que supera as impressões que tínhamos sobre distopia.

Há um século, o futuro ainda existia como algo desenhado numa linha do horizonte, algo sempre como uma miragem à frente. O espaço entre a linha especulativa do futuro e a borda de praia do presente começou drasticamente a ser encurtado. As ideias principais por trás dessas distopias da ficção, como exploração sem sustentabilidade dos recursos naturais, colapsos ecossistêmicos, acompanhado por regimes de ultradireita que aprofundam o fosso entre ricos e pobres, tornaram-se realidades diárias em todo o mundo. Dessa forma, a pressão imaginária do presente sobre si mesmo criou uma intensificação sufocante, presa num looping de eterno presente, sem conseguir lançar projeções de futuro. Na hiper-realidade que se experimenta contemporaneamente, não há espaço para o futuro como algo que se sonha mas, pelo contrário, como uma situação iminente e inevitável. Se as circunstâncias do presente corroboram com imagens do futuro projetadas ao longo do último século, o que se pode pensar do futuro a partir de hoje reflete a completa desesperança que os filmes apresentados nessa prancha conseguem reunir.

Por último, vemos nas imagens da prancha trabalhada para esse artigo a pathosformel da perda de uma humanidade manifestado em diferentes potências, algumas mais introspectivas, outras, de forma mais explosiva. Somos expostos à complexidade afetiva que é a projeção contemporânea do corpo do futuro. O homem contemporâneo teme que essas intervenções tecnológicas o transformem permanentemente em um ser sem vida, sem identidade e sensibilidade. Essas imagens constroem, a partir de diferentes lugares simbólicos, uma sensação pessimista com o futuro, como se o próximo passo evolutivo de nossa espécie estivesse no próprio apagamento da alma humana.

Eduardo Duarte é professor no Programa de Pósgraduação em Comunicação na Universidade Federal de Pernambuco. É doutor em ciências sociais pela Pontifícia Universidade Católica de São Paulo.

edwartte@gmail.com 
Gustavo Ramos é jornalista e mestrando no Programa de Pós-graduação em Comunicação na Universidade Federal de Pernambuco.

gustavoramosus@gmail.com

Contribuições de cada autor: Eduardo Duarte - supervisão e gestão do Projeto de Pesquisa, fundamentação teórica e conceituação, metodologia e escrita da segunda redação, revisão e edição final, obtenção de financiamento. Gustavo Ramos - curadoria de dados, escrita da primeira redação, investigação de campo, análise formal do corpus, construção de figuras e tabelas.

\section{Referências}

BATARCE, R. 964 PINOCCHIO (Shozin Fukui - 1991). Película Raivosa. 2011. Disponível em: <https://pelicularaivosa.wordpress.com/2011/03/14/964-pinocchio-shozin-fukui-\%E2\%80\%93-1991/>. Acesso em: out. 2019.

BERARDI, F. Depois do Futuro. São Paulo: Ubu editora, 2019.

DUARTE, E. A Fábula Restante dos Últimos Homens. Recife: Ed. Universitária. 2004. .; SEVERIEN, P. A insustentável leveza do deixar de ser. In: ARAUJO, D.; BARROS, A. T.; CONTRERA, M.; ROCHA, R. M. (Org.). IMAG (EM) INÁRIO. São Paulo: Imaginalis. p. 2018.

GERGEN, K. J. Technology and the self: From the essential to the sublime. In: GRODIN, D.; THOMAS, L. R. (Ed.). Constructing the self in a mediated world. California: Sage Publications, 1996.

JOHNSON, C. D. Memory, metaphor, and Aby Warburg's Atlas of images. Ithaca: Cornell University Press, 2012.

LEAKEY,R. A Evolução da Humanidade. São Paulo: Melhoramentos, 1981.

LE BRETON, D. Adeus ao corpo: Antropologia e sociedade. Campinas: Papirus, 2017.

MACIEL, J. C. S. Atlas mnemosyne e saber visual. In: Revista Ícone. Recife: PPGCOM/UFPE, 2018.

MICHAUD, P. A. Aby Warburg e a imagem em movimento. Rio de Janeiro: Contraponto. 2013.

MILLS, T. How French Artists in 1899 Envisioned Life in the Year 2000: Drawing the Future. OPEN CULTURE, 2015. Disponível em: <http://www.openculture.com/2015/09/ how-french-artists-in-1899-envisioned-life-in-the-year-2000.html\#comments>. Acesso em: 15 set. 2018. 
MINOIS, G. História do Futuro - dos profetas à prospectiva. São Paulo: UNESP. 2015

MORIN, E. O cinema ou o homem imaginário: ensaio de antropologia sociológica. São Paulo: É Realizações, 2014.

MOORE, S. Tetsuo: The Iron Man and the dark side of transhumanism. The Little White Lies. Disponível em: <https://lwlies.com/articles/tetsuo-the-iron-man-and-the-dark-side-oftranshumanism/>. Acesso em: 10 out. 2019.

SIBILIA, P. O Homem pós Orgânico - a alquimia dos corpos e das almas à luz das tecnologias digitais. Rio de Janeiro: Contraponto. 2014.

THOLOZANY, P. The Expositions Universelles in Nineteenth Century Paris. Brown University. Disponível em: <https://library.brown.edu/cds/paris/worldfairs.html\#de1900>. Acesso em: 10 out. 2018.

Artigo recebido em 13/05/2021 e aprovado em 22/06/2021. 